\title{
Hepatitis C: sexual or intrafamilial transmission? Epidemiological and phylogenetic analysis of hepatitis $C$ virus in 24 infected couples
}

\author{
Hepatite C: transmissão sexual ou intrafamiliar? Análise epidemiológica e \\ filogenética do vírus da hepatite $\mathrm{C}$ em 24 casais infectados
}

\author{
Norma de Paula Cavalheiro', Abel De La Rosa², Slava Elagin ${ }^{3}$, Fátima Mitiko Tengan', \\ Evaldo Stanislau Affonso de Araújo ${ }^{1}$ and Antonio Alci Barone ${ }^{1}$
}

\begin{abstract}
The role of sexual or intrafamilial transmission of hepatitis $\mathrm{C}$ is controversial. A phylogenetic analysis was performed on the non-structural region 5B of the hepatitis C virus (NS5B-HCV). High percentages of homology (mean of 98.3\%) were shown between the couples. Twenty ( $83.3 \%$ ) of the 24 men but only two of the women (8.3\%) reported having had sexually transmitted diseases during their lives. The risk factors for HCV acquisition were blood transfusion (10 couples), use of illegal injected drugs (17), use of inhalants (15), acupuncture (5) and tattoos (5). The shared use of personal hygiene items included toothbrushes between six couples (25\%), razor blades between 16 (66.7\%), nail clippers between 21 (87.5\%) and manicure pliers between 14 (58.3\%). The high degree of similarity of the hepatitis $\mathrm{C}$ virus genome supports the hypothesis of hepatitis $\mathrm{C}$ virus transmission between these couples. The shared use of personal hygiene items suggests the possibility of intrafamilial transmission of infection
\end{abstract}

Key-words: Intrafamilial. Hepatitis C virus. Sexual transmission. Heterosexual. Phylogeny.

\section{RESUMO}

0 papel da transmissão sexual ou intrafamiliar da hepatite C é controverso. Foi feita análise filogenética, região não estrutural 5B do vírus da hepatite C (NS5B-HCV). Altas percentagens de homologia com média de $98,3 \%$ foi revelada entre os casais. Vinte (83,3\%) de 24 homens, contra apenas duas $(8,3 \%)$ mulheres reportaram doença sexualmente transmisível durante suas vidas. Os fatores de risco para aquisição da doença foram: transfusão de sangue para 10 casais, uso de drogas ilícitas injetáveis para 17, inalatórias para 15, acupuntura em 5 e tatuagens para 5. 0 compartilhamento de utensílios de higiene pessoal incluem: escova de dente para seis (25\%) dos casais, lâmina de barbear para 16 (66,7\%), cortador de unhas para 21 (87,5\%) e alicate de manicure para 14 (58,3\%). 0 alto grau de similaridade genômica entre os vírus da hepatite C suporta a hipótese de transmissão entre os casais. 0 uso compartilhado de utensílios de higiene pessoal sugere a possibilidade de transmissão intrafamiliar.

Palavras-chaves: Intrafamiliar. Vírus da hepatite C. Transmissão sexual. Heterosexual. Filogenia.

Alter et $\mathrm{al}^{1}$ were the first to discuss the possibility of sexual transmission of the hepatitis $\mathrm{C}$ virus (HCV), and they suggested that multiple sexual partners were a risk factor. However, the importance of sexual transmission of HCV remains controversial, with transmission rates ranging from 0.5 to $2 \%$ per year of relationship reported in the literature. These low rates, associated with the scarcity of risk factors, suggest that there may be little or no risk of sexual transmission ${ }^{12}$. On the other hand, Tengan et al ${ }^{25}$ analyzed the sexual transmission of HCV in a Brazilian population and found prevalence of $11.8 \%{ }^{25}$.

\footnotetext{
1. Hepatitis Laboratory, Medical School, University of São Paulo, SP, Brazil. 2. Pharmasset Inc, Atlanta, Georgia, USA. 3. Third Wave Molecular Diagnostics, Madison, Wisconsin, USA.

Address to: Dra. Norma de Paula Cavalheiro. Hepatitis Laboratory, Infectious Diseases Departament, Medical School/USP. Rua Paraguassu, 174/141. 05006-010 São Paulo, SP, Brazil.

Tel: 5511 3085-1601; Fax: 5511 3085-1601.

e-mail: norma@usp.br

Received in 10/07/2008

Accepted in 14/04/2009
}

The intrafamilial transmission rates are significantly higher between sexual partners than among other household members who do not have sexual contact. Transmission to children is significantly low ${ }^{23}$. The findings from investigations involving specific populations such as patients at sexually transmitted disease (STD) clinics attending drug users, homosexuals or sex workers differ from those obtained from general populations, with higher observed risk of HCV transmission ${ }^{72126}$. In a review, Cavalheiro ${ }^{5}$ reported that sexual transmission of HCV does occur, but at a frequency much lower than that observed for other viruses such as the hepatitis B virus (HBV) or the human immunodeficiency virus (HIV) ${ }^{5}$.

Considering subjects who do not belong to high-risk groups but are HCV carriers, the question that arises is what risk there is of non-sexual transmission to their uninfected partners. This issue needs to be carefully addressed and evaluated. Another factor is the presence of HCV in fluids such as semen, saliva and menstrual blood from which the virus has been isolated. However, the 
potential for transmission is debatable. Nonetheless, it is certain that trauma to the mucosa during sexual intercourse increases the risk of transmission in the case of high viremia levels and a positive polymerase chain reaction (PCR) result from semen ${ }^{924}$.

In the present study, we analyzed factors relating to sexual and intrafamilial relationships in Brazilian heterosexual couples. Twenty-four couples with a clinical and laboratory diagnosis of HCV were studied. Virological analysis was complemented by phylogenetic analysis of the non-structural 5B (NS5B) region of the virus and the homology among genomic sequences was evaluated.

\section{MATERIAL AND METHODS}

Patients. Forty-five couples with a clinical and laboratory diagnosis of HCV infection were evaluated between January 1999 and December 2002. Of these, 24 met the inclusion criteria and were included in the study. These patients were recruited from the daytime clinics of the Hepatitis Division of the Infectious and Parasitic Diseases Clinic, University of São Paulo, Brazil, and from the Hepatitis Division of the Guilherme Álvaro Hospital, Santos, Brazil. Both hospitals are referral centers for patients with a diagnosis of hepatitis.

The individuals included in the study were HCV-positive couples, i.e. both partners had a positive polymerase chain reaction - hepatitis $\mathrm{C}$ virus (PCR-HCV) result and neither partner was coinfected with HIV or HBV. The couples who were excluded present anti-HCV antibodies positive and no detectable PCR-HCV in the serum of one or both partners.

The patients were interviewed privately using a standardized questionnaire, to collect demographic data and information on risk factors for HCV acquisition and sexual behavior. Blood was collected from the patients by vacuum venipuncture using a dry 10-ml tube. The serum was separated, centrifuged, aliquoted and stored at $-85^{\circ} \mathrm{C}$ until the time of use. After blood sample collection, HCV PCR testing was carried out, followed by genotyping and phylogenetic analysis based on sequencing of the HCV 5 NC and NS5B region.

All patients recruited for the study signed a free and informed consent statement.

Virological methods. Trugene HCV 5'NC genotyping kit: the specimens were sequenced using the Trugene HCV 5'NC genotyping kit in accordance with the manufacturer's instructions (Siemens Health Care Diagnostics, Berkeley, CA, USA). This test uses 244-bp fragments from the 5'NC region of the HCV genome, previously amplified by means of RT-PCR using the Cobas Amplicor Hepatitis C test (Roche Molecular Systems, Inc, Branchburg, NJ, USA). The amplification products were purified using the QIAquick PCR purification kit (Qiagen, Inc., Valencia, CA, USA) before use in the Trugene assay. HCV sequences were collected and analyzed by means of the OpenGene DNA sequencing system using Gene Object sequence analysis software (GL 3.1.2) ${ }^{10}$.
Hepatitis C virus NS5B sequencing assay: All HCV samples were further analyzed using the Trugene HCV NS5 sequencing assay (Siemens Health Care Diagnostics). Prior to use, all specimens were processed using the Epicentre RNA Masterpure purification kit (Epicentre Technologies, Madison, WI, USA). A portion of the HCV NS5B region was amplified using the Titan One Step RT-PCR kit (Roche Applied Science, Mannheim, Germany) and was used directly in the Trugene NS5 sequencing assay. HCV NS5B sequences were analyzed by means of the OpenGene DNA sequencing system using GeneObject DNA analysis software in the HCV NS5B GeneLibrarian module ${ }^{1020}$

Phylogenetic analysis: The 156-bp sequences of the HCV NS5B region produced by the HCV NS5B sequencing assay (nt 8353 to 8508 ) were analyzed using the Phylip software package, version 3.5c. Distances between pairs of sequences were estimated using the DNA Dist program. All phylogenetic trees were constructed by means of the unweighted pair group method, using arithmetic averages on the previous sets of pairwise distances. Significance of the clustering was ensured by bootstrap resampling $(1,000$ replicates). GenBank sequences were included in the analysis. All patients are mentioned in terms of Arabic numbers and letters in the tree (example: $1 \mathrm{a} / 1 \mathrm{~b})^{81020}$.

\section{RESULTS}

Forty-five couples were recruited and 24 who met the inclusion and exclusion criteria participated in the study. The mean age of the patients was 48.9 years (range: 26-67), the mean duration of cohabitation was 22.0 years (range: $2-45$, mode: 30 , median: 23.5), and the mean frequency of sexual intercourse per month was 8.8 times (range: 1-30, mode: 12, median: 7.0 ). The mean annual income was US\$ 2,270.00.

Interestingly, nine patients $(18.8 \%)$ denied that they had all five of the risk factors (blood transfusions, injected and inhaled drug use, acupuncture and tattoos). All of these patients were females (2a, 4b, 12a, 18b, 20a, 23a, 24b, 26b and $31 \mathrm{~b}$ ) whose respective partners presented one or more of these risk factors. Couple \#7 was the only one in which neither partner presented any of the risk factors for HCV acquisition (Table 1).

The frequency of sharing personal hygiene items was high. No shared use of personal hygiene items was reported by five of the 48 patients (three women: $6 \mathrm{~b}, 9 \mathrm{~b}$ and $16 \mathrm{~b}$; and two men: $11 \mathrm{~b}$ and $22 \mathrm{~b}$ ). However, their partners admitted sharing the use of at least one of the items. There was no correlation between the patients who did not share their personal hygiene items and the nine women who presented no parenteral risk factor. However, seven of these nine women belonged to the group in which at least one of the partners admitted sharing the use of a razor blade. In the other two cases, sharing of nail clippers or manicure pliers was reported. For all couples, one or both partners admitted sharing the use of one or more of their personal hygiene items, except for the same couple that denied other parenteral risks (Table 2). 
TABLE 1

Distribution of the 24 couples in relation to risk factors for HCV acquisition (one or both partners).

\begin{tabular}{|c|c|c|c|c|c|c|c|c|c|c|}
\hline \multirow[t]{2}{*}{$\begin{array}{l}\text { Couples: one } \\
\text { or both partners } n^{0}=24\end{array}$} & \multicolumn{2}{|c|}{$\begin{array}{c}\text { Blood } \\
\text { transfusion }\end{array}$} & \multicolumn{2}{|c|}{$\begin{array}{l}\text { Injected } \\
\text { drug use }\end{array}$} & \multicolumn{2}{|c|}{$\begin{array}{l}\text { Inhaled } \\
\text { drug use }\end{array}$} & \multicolumn{2}{|c|}{ Acupuncture } & \multicolumn{2}{|c|}{ Tattoo } \\
\hline & $\mathrm{n}$ & $\%$ & $\mathrm{n}$ & $\%$ & $\mathrm{n}$ & $\%$ & $\mathrm{n}$ & $\%$ & $\mathrm{n}$ & $\%$ \\
\hline Yes & 9 & 37.5 & 17 & 70.8 & 15 & 62.5 & 4 & 16.7 & 5 & 20.8 \\
\hline No & 1 & 4.2 & 1 & 4.2 & 1 & 4.2 & 1 & 4.2 & 1 & 4.2 \\
\hline
\end{tabular}

TABLE 2

Distribution of the 24 couples in relation to shared use of personal hygiene items reported by one or both partners.

\begin{tabular}{|c|c|c|c|c|c|c|c|c|}
\hline \multirow{3}{*}{$\begin{array}{l}\text { Couples: one or } \\
\text { both partners } n^{0}=24\end{array}$} & & & \multirow{2}{*}{\multicolumn{2}{|c|}{$\begin{array}{l}\text { Razor } \\
\text { Blade }\end{array}$}} & \multirow{2}{*}{\multicolumn{2}{|c|}{$\begin{array}{c}\text { Nail } \\
\text { Clippers }\end{array}$}} & \multirow{2}{*}{\multicolumn{2}{|c|}{$\begin{array}{c}\text { Manicure } \\
\text { Pliers }\end{array}$}} \\
\hline & \multicolumn{2}{|c|}{ Toothbrush } & & & & & & \\
\hline & $\mathrm{n}$ & $\%$ & $\mathrm{n}$ & $\%$ & $\mathrm{n}$ & $\%$ & $\mathrm{n}$ & $\%$ \\
\hline Yes & 6 & 25.0 & 16 & 66.7 & 21 & 87.5 & 14 & 58.3 \\
\hline No & 1 & 4.2 & 1 & 4.2 & 1 & 4.2 & 1 & 4.2 \\
\hline
\end{tabular}

None of the couples reported acquiring any STDs over the past year, but there were reports of STDs acquired before that time. Twenty (83.3\%) of the 24 men but only two of the women (8.3\%) reported having had STDs during their lives (Table 3). In this group, 19 (79.2\%) men and none of the women reported having sexual intercourse with sex professionals (Table 4).

Among the 24 couples studied, 22 (91.7\%) presented correspondence between viral subtypes and high similarity in the HCV NS5B region (mean: $98.3 \%$; range: $93 \%$ to $99.4 \%$ ). The subtypes found are shown in Table 5. The two couples (8.3\%) who presented no corresponding HCV subtypes had comparison values of $70.1 \%$ and $82.2 \%$ respectively, and were infected with the $2 \mathrm{~b} / 1 \mathrm{~b}$ and $1 \mathrm{~b} / 1 \mathrm{a}$ viral subtypes.

The family represented by the codes $8 \mathrm{a}$ (father), $8 \mathrm{~b}$ (mother) and $8 \mathrm{c}$ (daughter) was analyzed, and the genome similarity showed the following percentages: $93.6 \%$ for $8 \mathrm{a} / 8 \mathrm{~b}, 93.6 \%$ for $8 \mathrm{a} / 8 \mathrm{c}$ and $99.4 \%$ for $8 \mathrm{~b} / 8 \mathrm{c}$.

TABLE 3

\begin{tabular}{|c|c|c|c|c|}
\hline \multirow[b]{2}{*}{ Sexualy transmitted diseases } & \multicolumn{2}{|c|}{ Males } & \multicolumn{2}{|c|}{ Females } \\
\hline & $\mathrm{n}^{0}$ & $\%$ & $\mathrm{n}^{0}$ & $\%$ \\
\hline Syphilis & 3 & 12.5 & 0 & 0.0 \\
\hline Chancre & 5 & 20.8 & 0 & 0.0 \\
\hline Gonorrhea & 16 & 66.7 & 1 & 4.2 \\
\hline Condyloma & 2 & 8.3 & 0 & 0.0 \\
\hline Herpes & 0 & 0.0 & 1 & 4.2 \\
\hline Crabs & 4 & 16.7 & 0 & 0.0 \\
\hline Trichomonas & 1 & 4.2 & 0 & 0.0 \\
\hline None & 4 & 16.7 & 22 & 91.7 \\
\hline
\end{tabular}

\section{TABLE 4}

Number of sexual relationships with casual partners and use of paid sex over lifetime reported by the 24 couples.

\begin{tabular}{|c|c|c|c|c|c|c|c|c|}
\hline \multirow{3}{*}{$\begin{array}{l}\text { Number } \\
\text { of partners }\end{array}$} & \multicolumn{4}{|c|}{ Males } & \multicolumn{4}{|c|}{ Females } \\
\hline & \multicolumn{2}{|c|}{$\begin{array}{c}\text { casual } \\
\text { partners }\end{array}$} & \multicolumn{2}{|c|}{$\begin{array}{l}\text { paid } \\
\text { sex }\end{array}$} & \multicolumn{2}{|c|}{$\begin{array}{c}\text { casual } \\
\text { partners }\end{array}$} & \multicolumn{2}{|c|}{$\begin{array}{l}\text { paid } \\
\text { sex }\end{array}$} \\
\hline & $\mathrm{n}$ & $\%$ & $\mathrm{n}$ & $\%$ & $\mathrm{n}$ & $\%$ & $\mathrm{n}$ & $\%$ \\
\hline None & 8 & 33.3 & 5 & 20.8 & 19 & 79.2 & 24 & 100.0 \\
\hline 1 & 2 & 8.3 & 1 & 4.2 & 2 & 8.3 & 0 & 0.0 \\
\hline 2 to 3 & 4 & 16.7 & 6 & 25.0 & 1 & 4.2 & 0 & 0.0 \\
\hline 4 to 10 & 6 & 25.0 & 11 & 45.8 & 2 & 8.3 & 0 & 0.0 \\
\hline 11 to 20 & 3 & 12.5 & 0.0 & 0.0 & 0.0 & 0 & 0 & 0.0 \\
\hline 21 to 50 & 1 & 4.2 & 1 & 4.2 & 0.0 & 0 & 0 & 0.0 \\
\hline 51 to 99 & 0 & 0.0 & 0.0 & 0.0 & 0.0 & 0 & 0 & 0.0 \\
\hline$\geq 100$ & 0 & 0.0 & 0.0 & 0.0 & 0.0 & 0 & 0 & 0.0 \\
\hline Total & 24 & 100.0 & 24 & 100.0 & 24 & 100.0 & 24 & 100.0 \\
\hline
\end{tabular}

A phylogenetic tree was constructed based on the sequences of the NS5B region of the HCV genome. The sequences (156 bp) were aligned using the Clustal W application (Clustal W Multiple Sequence Alignment Program v1.7, June 1997) and the phylogenetic tree was compiled from this alignment using the neighbor joining method available in the Philip 3.5c program (Figure 1).

\section{TABLE 5}

Distribution of the 22 couples with regard to hepatitis C virus subtype and genomic similarity.

\begin{tabular}{|c|c|c|c|}
\hline \multirow[t]{2}{*}{ Subtype HCV 5'NC and NS5B } & \multicolumn{2}{|c|}{ Number of couples } & \multirow{2}{*}{$\begin{array}{c}\text { Mean homology (NS5B) } \\
\%\end{array}$} \\
\hline & $\mathrm{n}$ & $\%$ & \\
\hline 1a & 2 & 8.3 & 99.4 \\
\hline $1 b$ & 9 & 37.5 & 97.7 \\
\hline $2 b$ & 1 & 4.2 & 98.7 \\
\hline $3 a$ & 10 & 41.7 & 97.5 \\
\hline Overall mean & 22 & 91.7 & 98.3 \\
\hline
\end{tabular}

HCV 5'NC: hepatitis C virus 5' nonconding, NS5B: non structural 5B 


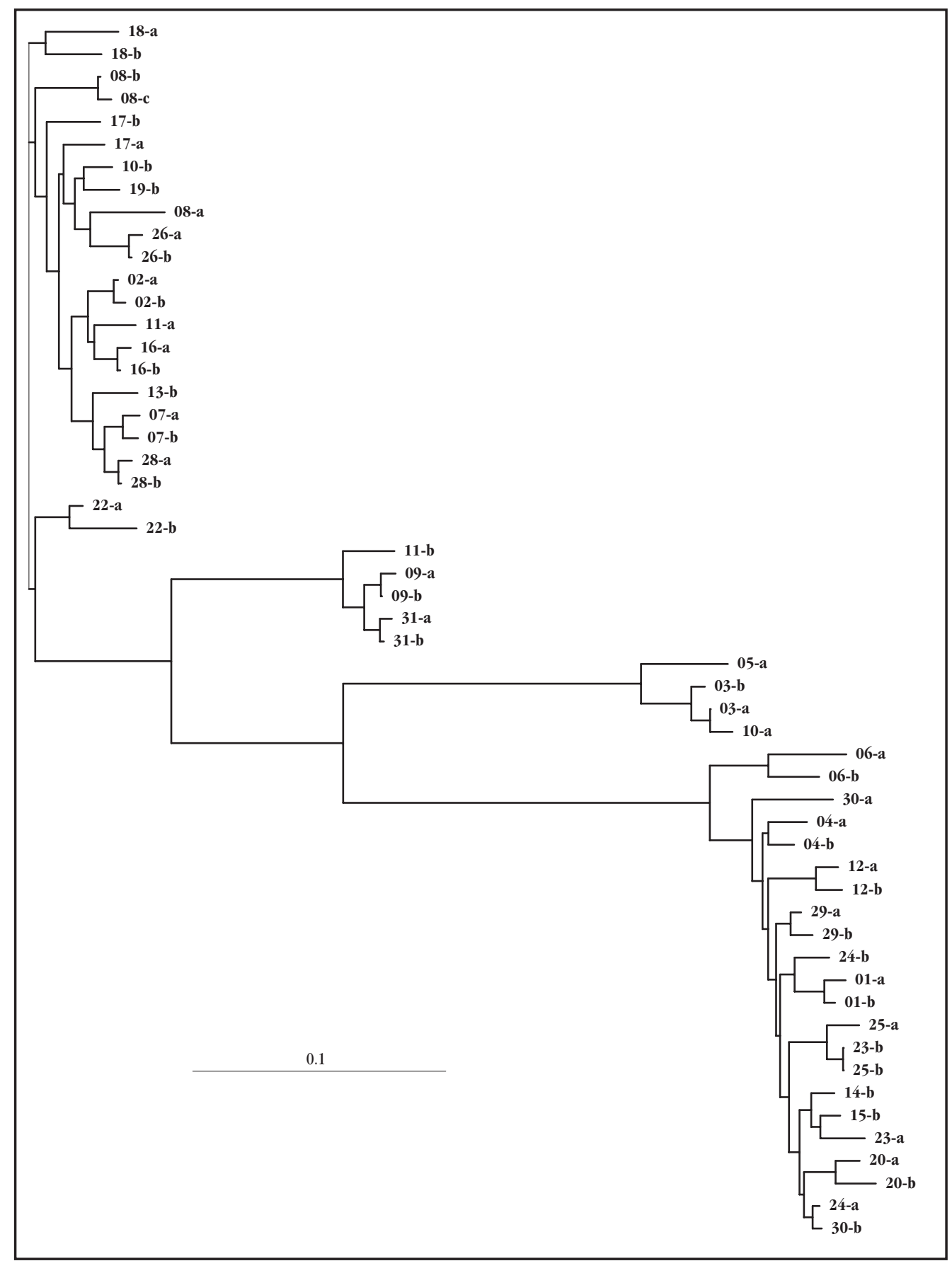

FIGURE 1

Phylogenetic tree representing the 24 couples analyzed.

\section{DISCUSSION}

Shared use of personal hygiene items was frequent among our population. While one partner may have been careful not to share items, in order to avoid transmission, the other partner did not necessarily emulate this behavior. This markedly increased the risk of intrafamilial transmission between spouses and also among other residents of the same household. The family represented by number 8 supports this hypothesis. The epidemiological investigation revealed that the adolescent daughter began shaving her legs, sharing her parents' razor blades. The highest similarity was observed between the mother and daughter, a finding supporting the hypothesis of intrafamilial transmission within this household. 
In the present sample, nine women presented no risk factors for HCV acquisition, whereas their partners presented one or more factors. Among the nine couples who shared one or more personal hygiene items, seven belonged to the group in which at least one of the partners admitted sharing the use of a razor blade. In the case of the other two couples, shared use of nail clippers or manicure pliers was reported. We believe that the inclusion of these cultural factors explains the high rates found here. The living habits of the household should be considered to be confounding factors when discussing sexual transmission. Thus, it cannot be said that HCV is only transmitted sexually. Rooney and Gilson ${ }^{21}$ showed that, in addition to familial and sexual behavioral patterns, shared used of personal hygiene items might be important for intrafamilial transmission of $\mathrm{HCV}^{162021}$. Only one of the couples that did not belong to the parenteral risk group for HCV acquisition also did not report shared use of personal items. For this couple, the similarity in the genomic HCV chains analyzed was $98.7 \%$. In this case, the possibility of sexual transmission of HCV was high, and this indicates the need for studies to further clarify this issue. Minola et $\mathrm{al}^{17}$ and La Torre ${ }^{13}$ stated that the risk of sexual transmission of HCV should not be underestimated, although other non-sexual factors of intrafamilial contact have not been completely understood ${ }^{1317}$.

Among the population studied, the women were on average five years younger than their partners and had practically no extramarital sexual experience (Table 4). Sexual transmission of HCV involves a wide range of issues that should be addressed when discussing this subject. One aspect is the number of sexual partners ${ }^{1}$. Mele et $\mathrm{al}^{15}$ found that the risk was twice as high among those who reported having two sexual partners and 2.8 times as high among those who reported having three partners ${ }^{15}$. Furthermore, Salleras et $\mathrm{a}^{22}$ showed that the risk of HCV transmission among subjects with four partners or more was 14 times higher, whereas it was only three times higher among those who reported having two or three partners ${ }^{6}{ }^{1522}$. Hershow et $\mathrm{al}^{11}$ identified sexual promiscuity, intravenous drug users as sexual partners, associated STDs, paid sex and a long time living with an HCV-positive partner as significant risk factors for HCV infection $^{11}$.

Sexual promiscuity, use of illegal drugs and the presence of STDs before entering a stable relationship with the current partner were strong risk factors among men. This increases the possibility that these men might have acquired HCV infection before their partners did. The data suggest that these men were more exposed to risk factors than their partners were and that the chances of prior acquisition of HCV infection seem to be more evident among men. These findings support the hypothesis of male-to-female transmission of HCV in this group. Interestingly, supporting this hypothesis, there were nine (18.8\%) individual cases in which the subjects denied having the five risk factors that were described. All of them were women who, together with their respective partners, presented one or more factors. Taken together, these data provide further evidence for male-to female transmission of HCV. These nine couples support the hypothesis of probable male-to-female transmission.
Minola et $\mathrm{al}^{17}$ studied HCV transmission among sexual partners and reported that the risk of HCV transmission increased by $13.2 \%$ when the partners used illegal drugs ${ }^{17}$. In our sample, the couples reported long periods of living together and showed high levels of genome similarity. The relationship between the length of time partners live together and sexual transmission of HCV is a controversial issue. The literature emphasizes the need for long periods of cohabitation to explain HCV transmission, although there are reports of acute infection in which the single risk factor is a sexual partner who was HCV-positive ${ }^{3181921}$. In a review, Rooney and Gilson ${ }^{21}$ reported that the estimated risk of HCV infection was 1.5 (confidence interval: 1.05-2.2) per decade of marriage. In addition, women with HCV-positive partners presented a 3.7 times higher chance of contracting the disease ${ }^{112127}$.

In the case of HCV-positive patients, it is still not possible to clearly distinguish between those who present a potential for sexually transmitting HCV and those who do not. In addition, for long-lasting relationships in which the index case presents low viremia and the partner is HCV-negative, the possibility of transmission of the infection in the future cannot be ruled out ${ }^{12}{ }^{19}$.

The NS5B region was chosen for phylogenetic analysis since this region is not susceptible to high levels of immune pressure. Norder et $\mathrm{a}^{20}$ reported that this region is a powerful tool for investigating nosocomial transmission of HCV, emphasizing the fact that many of the chains analyzed belong to the same viral subtype $^{20}$.

Although all of the 21 couples excluded presented anti-HCV antibodies positive and the PCR-HCV could not be detected in the serum of one or both partners. This made it impossible for them to be kept in the study, since comparison of genomic chains was essential.

Twenty-two couples studied here showed correspondence among viral subtypes and high rates of genome similarity. The distribution of HCV types observed was compatible to that reported by Cavalheiro et $\mathrm{al}^{4}$ for a Brazilian population ${ }^{4}{ }^{14}$. The high percentage of similarity suggests that the partners were infected with the same virus or that the infection was acquired from a common source, thereby indicating transmission from one partner to the other.

The NS5B region was the target in the study by Zylberberg et $\mathrm{a}^{28}$ conducted at a hepatology clinic on seven couples with the same genotype, three of them showing $98 \%$ similarity, corresponding to a difference of one to three nucleotides ${ }^{28}$. The homology between the sequences suggests that the source of infection was the same for both partners, or that transmission from one partner to the other took place. However, it is not possible to confirm where and how the infection was contracted, whether from an external source through shared use of personal hygiene items or through sexual intercourse. According to Terrault ${ }^{26}$, comparison of genetic sequences between concordant couples has been used as evidence for the occurrence of transmission, but this evidence does not allow confirmation of the transmission route. Nevertheless, this strongly suggests that sexual transmission occurs when no other associated risk factor is present ${ }^{26}$.

Phylogenetic analysis on HCV is a powerful and precise tool for virological investigation, particularly when evaluating HCV 
transmission. However, this technique should be used carefully and judiciously, for it to be useful for understanding HCV infection. If our study were based solely on virological interpretation, without support from epidemiological data, we might well reach very different conclusions from those presented here. Furthermore, a study based only on epidemiological findings runs the risk of being incomplete.

In conclusion, the high similarity found among genomic chains supports the hypothesis that HCV transmission occurs between partners. The shared use of personal hygiene items makes it difficult to interpret the data in terms of sexual transmission of HCV and suggests that intrafamilial transmission is a likely infection route. The present study supports the hypothesis that male-to-female transmission of HCV is likely.

\section{ACKNOWLEDGMENTS}

The authors thank Mr. Jim MacMenamim for his invaluable help with this study.

\section{REFERENCES}

1. Alter MJ, Coleman PJ, Alexander WJ, Kramer E, Miller JK, Mandel E, Hadler SC, Margolis HS. Importance of heterosexual activity in the transmission of hepatitis B and non-A, non-B hepatitis JAMA 262: 1201-1215, 1989.

2. Brook MG, Sexually acquired hepatitis. Sexual Transmitted Infections 78: 235$240,2002$.

3. Capelli C, Prati D, Bosoni P, Zanuso F, Pappalettera M, Mozzi F, De Mattei C, Zanella A, Sirchia G. Sexual transmission of hepatitis C virus to a repeat blood donor. Transfusion 37: 436-440, 1997.

4. Cavalheiro NP, Barone AA, Tengan FM. HCV Serotypes in Brazilian patients. International Journal of Infectious Diseases 6: 228-232, 2002.

5. Cavalheiro NP. Sexual transmission of Hepatitis C - Review Revista do Instituto de Medicina Tropical de São Paulo 49: 271-277, 2007.

6. Chayama K, Kobayashi M, Tsubota A, Koida I, Arase Y, Saitoh S, Ikeda K, Kumada $\mathrm{H}$. Molecular analysis of intraspousal transmission of hepatitis C virus. Journal of Hepatology 22: 431-439, 1995.

7. Daikos GL, Lai S, Fischl MA. Hepatitis C virus infection in a sexually active inner city population. The potential for heterosexual transmission. Infection 22: 72-76, 1994

8. Felsenstein J. Phylip (phylogenetic Inference Package). University of Washington, Seattle, 1993.

9. Ferreiro MC, Dios PD, Scully C. Transmission of hepatitis C virus by saliva? Oral Diseases 11: 230-235, 2005.

10. Germer JJ, Majewski DW, Rosser M, Thompson A, Mitchell PS, Smith TF, Elagin S, Yao JD. Evaluation of the Trugene HCV 5'NC genotyping kit with the new geneLibrarian Module 3.1.2 for genotyping of hepatitis $\mathrm{C}$ virus from clinical specimens. Journal of Clinical Microbiology 41: 4855-4857, 2003.
11. Hershow RC, Kalish LA, Sha B, Till M, Cohen M. Hepatitis C virus infection in Chicago women with or at risk for HIV infection: evidence for sexual transmission. Sexual Transmitted Diseases 25:527-532, 1998.

12. Kumar RM. Interspousal and intrafamilial transmission of hepatitis $C$ virus: a myth or a concern? Obstetrics and Gynecology 91: 426-431, 1998.

13. La Torre G, Miele L, Mannocci A, Chiaradia G, Berloco F, Gabrieli ML, Gasbarrini G, Ficarra MG, Matera A, Ricciardi G, Grieco A. HCV-Southern Lazio Collaborative Group. Correlates of HCV seropositivity among familial contacts of HCV positive patients. BMC Public Health, 25: 237, 2006.

14. Levi JE, Takaoka DT, Garrini RH, Fachini RM, Focaccia R, De Bortholi Santos E, Mitre HP, De Mendonça JS, De Paula Cavalheiro N, Barone AA, Wendel S.Three cases of infection with hepatitis $\mathrm{C}$ virus genotype 5 among Brazilian hepatitis patients. Journal of Clinical Microbiology 40: 2645-2647, 2002.

15. Mele A, Stroffolini T, Tosti ME, Corona R, Santonastasi F, Gallo G, Ragni P, Balocchini E, Bernacchia R, Moiraghi A. Heterosexual transmission of hepatitis C in Italy. Journal Medical Virology 57: 111-113, 1999.

16. Memon MI, Memon MA. Hepatitis C: an epidemiological review. Journal Viral Hepatology 9: 84-100, 2002

17. Minola E, Baldo V, Baldovin T, Trivello R, Florean A. Intrafamilial transmission of hepatitis C virus infection. European Journal Epidemiology 21:293-297, 2006.

18. Morsica G, Sitia G, Bernardi MT, Tambussi G, Novati R, De Bona A, Gianotti N, Lazzarin A. Acute self-limiting hepatitis $\mathrm{C}$ after possible sexual exposure: sequence analysis of the $\mathrm{E}-2$ region of the infected patient and sexual partner. Scandinavian Journal of Infection Diseases 33: 116-120, 2001.

19. Nakayama H, Sugai Y, Ikeya S, Inoue J, Nishizawa T, Okamoto H. Molecular investigation of interspousal transmission of hepatitis $\mathrm{C}$ virus in two Japanese patients who acquired acute hepatitis $\mathrm{C}$ after 40 or 42 years of marriage. Journal of Medical Virolology 75: 258-266, 2005.

20. Norder H, Bergström A, Uhnoo I, Aldén J, Weiss L, Czajkowski J, Magnius L. Confirmation of nosocomial transmission of hepatitis $\mathrm{C}$ virus by phylogenetic analysis of the NS5-B region. Journal of Clinical Microbiology 36: 3066-3069, 1998.

21. Rooney G, Gilson RJ. Sexual transmission of hepatitis C virus infection. Sexual Transmitted Infections 74: 399-404, 1998.

22. Salleras L, Bruguera M, Vidal J, Plans P, Domínguez A, Salleras M, Navas E, Galí N. Importance of sexual transmission of hepatitis $\mathrm{C}$ virus in seropositive pregnant women: a case-control study. Journal Medical Virology 52: 164-167, 1997.

23. Saltoglu N, Tasova Y, Burgut R, Dundar IH. Sexual and non-sexual intrafamilial spread of hepatitis C virus: intrafamilial transmission of HCV. European Journal Epidemiology 14: 225-228, 1998.

24. Silverman AL, Puccio JE, Kulesza GW, McCray DG, Gordon SC. HCV RNA is present in the menstrual blood of women with chronic hepatitis $\mathrm{C}$ infection. American Journal of Gastroenterology 89: 1201-1202, 1994.

25. Tengan FM, Eluf-Neto J, Cavalheiro NP, Barone AA. Sexual transmission of hepatitis C virus. Revista do Instituto de Medicina Tropical de São Paulo 43: 133-137, 2001.

26. Terrault NA. Sexual activity as a risk factor for hepatitis C. Hepatology 36:S99S105, 2002

27. Thomas DL, Zenilman JM, Alter HJ, Shih JW, Galai N, Carella AV, Quinn TC. Sexual transmission of hepatitis $\mathrm{C}$ virus among patients attending sexually transmitted disease clinics in Baltimore - an analysis of 309 sex partnership. Journal of Infectious Diseases 171: 768-775, 1995.

28. Zylberberg H, Thiers V, Lagorce D, Squadrito G, Leone F, Berthelot P, Bréchot C, Pol S. Epidemiological and virological analysis of couples infected with hepatitis C virus. GUT 45: 112-116, 1999. 